ANTHRACNOSE - DISEASE OF THE ASPBERRY AND RELATED PLANTS

\author{
Bis. nister \\ JUN 211918
}

A THESIS

Presented to the Faculty of the Graduate School of CORNELL UnIVERsity for tHe DEgree of DOCTOR OF PHILOSOPHY

BY

WALTER H. BURKHOLDER

Reprint of Cornell University Agricultural Experiment Station Bulletin 395 , Növember, 1917 



\title{
THE ANTHRACNOSE DISEASE OF THE RASPBERRY AND RELATED PLANTS
}

\author{
A THESIS \\ Presented to the Faculty of the Graduate School \\ of Cornell University for the Degree of \\ DOCTOR OF PHILOSOPHY
}

BY

WALTER H. BURKHOLDER

Reprint of Cornell University Agricultural Experiment Station Bulletin 395, November, 1917 
i) 


\section{CONTENTS}

History and geographical distribution of the disease........... I 59 Economic importance . . . . . . . . . . . . . . . . . . . I 59

Symptoms. . . . . . . . . . . . . . . . . . . . . . I6o

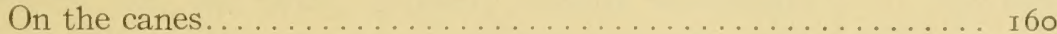

On petioles and pedicels.................... $6_{3}$

On the leaves............................ $6_{3}$

Etiology . . . . . . . . . . . . . . . . . . . . $6_{4}$

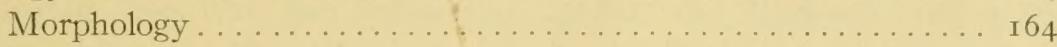

Nomenclature... . . . . . . . . . . . . . . . . . . . . . . I 66

Life history . . . . . . . . . . . . . . . . . . . . . 67

The ascigerous stage ..................... I67

The imperfect stage ...................... I69

Pathological histology . . . . . . . . . . . . . . . . . . . . . . . . . . . . .

Cultural characters . . . . . . . . . . . . . . . . . . . . . .

Inoculation experiments . . . . . . . . . . . . . 74

Inoculations with spores from the Gloeosporium stage. . . . . I 74

Inoculations with spores from the ascigerous stage. . . . . I 75

Cross-inoculations. . . . . . . . . . . . . 77

The effect of weather conditions. . . . . . . . . . . . . . . . . . .

Control........................... I $^{8}$

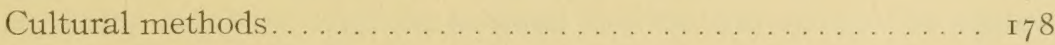

Spraying . . . . . . . . . . . . . . . . . . . . . . . . . .

Bibliography ..................... I 82 



\section{THE ANTHRACNOSE DISEASE OF -THE RASPBERRY AND RELATED PLANTS'}

\section{WALTER H. BURKholder}

The raspberry is one of the oldest of the small fruits. It belongs to the genus Rubus, of the family Rosaceae, ${ }^{2}$ and comprises a number of varieties which with a few exceptions originated from three main sources the European red raspberry (Rubus idaeus L.), and the two American species, the red raspberry (Rubus idaeus var. aculeatissimus [Mey.] Regel \& Tiling) and the black raspberry (Rubus occidentalis L.). The first of these three species was under cultivation as early as the fourth century, but the domestication of the other two is of very recent date.

Most of the commercial varieties of the raspberry in North America originated from the two indigenous species, the European red raspberry not being sufficiently hardy and vigorous to withstand the climatic conditions of this country. Two hybrids also are grown extensively here. They are the purple-cane raspberry, formerly known as Rubus neglectus Peck but now claimed by Anthony ${ }^{3}$ to be a cross between the red and the black raspberry; and the loganberry, considered to be a hybrid between the European red raspberry and the western dewberry (Rubus vitifolius Cham. \& Schlecht.).

In the United States these berries are grown throughout the northern part of the country and in the cooler hilly regions. According to the Thirteenth Census Report, New York State in I9ro ranked first in the production of this fruit, with II,057 acres, and Michigan second, with 8786 acres; no other State had as much as 4000 acres. In New York the raspberry industry is limited to small districts throughout the western part of the State, with the exception of an area in the Hudson River Valley. In these localities during the past ten years or more there has been a marked decrease both in acreage and in yield, which is attributed to the general prevalence of diseases to which the host is susceptible.

The anthracnose disease, yellows, cane blight, and crown gall are the commonest diseases affecting the raspberry. Anthracnose occurs in practically every locality and is considered the most serious disease of

1 Also presented to the Faculty of the Graduate School of Cornell University, June, I9I7, as a thesis in partial fulfillment of the requirements for the degree of doctor of philosophy.

AUTHOR's ACKNOWLEDGMENTS. The writer wishes to express his indebtedness to Professor Donald Reddick, under whose direction the work was performed, and to Professor V. B. Stewart for help and criticism in preparation of the manuscript.

${ }_{2}$ Card, Fred W. The brambles. In Bush-fruits, p. 43-336. Igr4.

3 Anthony, R. D. Some notes on the breeding of raspberries. New York (Geneva) Agr. Exp. Sta. Bul. $417: 75-88$. I9I6. 
the plant. It is known also as cane rust, spot, scab, or sun-scald. It occurs on all the above-named species of Rubus and their hybrids, and in addition is found on various other species of this genus, such as the blackberry (Rubus sp.), the eastern and the western dewberry (Rubus villosus Ait. and Rubus vitifolius Cham. \& Schlecht.), the cloudberry (Rubus chamaemorus L.), and the European bramble (Rubus fruticosus L.). Halsted $(1894)^{4}$ has suggested that the anthracnose of the rose may be identical with that of the raspberry, but this has not been proved.

Of the species of Rubus affected by anthracnose, the black raspberry (Rubus occidentalis) exhibits the greatest susceptibility to the disease. On this species the disease is very severe, not only on the cultivated varieties but also on the wild forms. Observations show, moreover, that the hybrid generally known as Rubus neglectus has inherited this susceptibility, and anthracnose occurs commonly in plantations where this hybrid is grown. On the other hand, the commercial varieties of the red raspberry, which arise mainly from Rubus idaeus var. aculeatissimus, show a marked resistance to the disease. Very few fields planted with these varieties have been observed where the anthracnose was considered to be of any economic importance. Furthermore, it is noticeable that on the wild forms of this species the disease seldom occurs except on the leaves, where it is never serious. In New York State the blackberry is rarely subject to anthracnose, but according to Lawrence (r9ro) and Jackson (I9I3) it is very susceptible to the disease in the northwestern United States. Anthracnose is more or less injurious also to the dewberry and the loganberry.

Varietal susceptibility is not markedly perceptible within the abovenamed species. Taylor ${ }^{5}$ reports a desirable black raspberry, the Hoosier, which is considered to be resistant; at least it has remained free from the anthracnose disease up to the present time. Among the varieties of the red raspberry the Cuthbert is held to be the most resistant, though all the varieties of this species exhibit but very little susceptibility. The Columbian, a purple-cane variety, formerly was regarded as nearly immune, but it now exhibits a marked susceptibility. It is not known whether this variety really possessed resistance at one time or whether the stock was merely free from the disease. At present very few growers recognize any difference in susceptibility between the black raspberry and the purple-cane varieties. Lawrence (I910) states that among the varieties of blackberry the disease is severe on the Snyder and the Kittatany, while on the Himalaya Giant it occurs only on the leaves.

1 Dates in parenthesis refer to bibliography, page 182.

5 Taylor, William A. Hoosier raspberry. In Promising new fruits. U. S. Dept. Agr. Yearbook 1910:429-430. 1911 . 


\section{HISTORY AND GEOGRAPHICAL DISTRIBUTION OF THE DISEASE}

The anthracnose disease is possibly of as widespread distribution as the raspberry itself. Massee ( 1907 ) states that it occurs in Europe, America, and Australia but has been found more commonly on the last two continents. The disease was first reported in Italy, by Spegazzini (i 879), on the leaves of the cloudberry (Rubus chamaemorus). The following year it was brought to the attention of Burrill (1882) in America, where in certain localities it was causing serious losses to the black raspberry crop.

It is thus difficult to determine whether anthracnose is of American or European origin. The disease has been more destructive in America, doubtless due to the fact that the most susceptible species of the genus Rubus are under cultivation here. Cooke (I906) even expresses doubt that the disease is to be found in England, and Sorauer (I908) does not mention its occurrence in Germany. On the other hand, the disease spread rapidly in America, and ten years after it was first noticed, in Italy, Scribner (I888) reports it as being widespread and destructive in the United States. Dearness collected diseased material in Canada in I89I and contributed it to the exsiccati of Seymour and Earle's Economic Fungi. A few years later McAlpine (I897) reported it from Australia.

\section{ECONOMIC IMPORTANCE}

It is difficult to estimate the losses caused by anthracnose, since the disease varies greatly with climatic conditions and the host plant is often subject to less striking diseases which are nevertheless of considerable importance. Such diseases as yellows and crown gall are frequently overlooked and their injury to the plant attributed to anthracnose when that is present. No doubt the estimates of losses due to anthracnose have been in some cases too high, although it is one of the most serious diseases of the raspberry. For these reasons, and from the fact that the disease affects the plant only indirectly, little data are available showing the percentage of loss caused by anthracnose. A few investigators, however, have made estimates which may be mentioned here.

Burrill (I 882) cites an instance of a raspberry plantation ordinarily yielding a profit of $\$ 400$ per year, which profit was reduced to such an extent by one attack of anthracnose that expenses were scarcely met. Scribner (I888) estimates the losses in southern Missouri on the blackcap raspberry as being from ten to twelve per cent of the entire crop. The disease is reported by Orton and Ames (I908) to have injured sixty-three per cent of the raspberry crop in Nebraska, fifty per cent in Wisconsin, and even a greater percentage in Illinois. Lawrence (I9IO) cites instances 
in which the percentage of infected blackberries at certain pickings was as high as fifty.

Even more striking is the fact that in certain localities in New York State the growers have been obliged to discontinue the raising of berries. They attribute the cause of the failure of the crop to the anthracnose disease. In a report of a survey of small fruits in western New York, Buchholz (I9II) states that by a conservative estimate seventy-five per cent of the black raspberry patches were diseased with anthracnose. He states also that the average yield of the raspberry, at one time, was two thousand quarts per acre in this section, while now even in favorable years it is difficult to obtain this quantity. Furthermore a plantation . formerly yielded a crop annually for a period of from six to seven seasons, while in recent years only about four crops are harvested from a plantation. That a correlation exists between the general prevalence of the anthracnose disease and the reduction in yield of the crop in late years is evident.

\section{SYMPTOMS}

The anthracnose disease appears on the canes, the petioles, the pedicels, and the leaves of the raspberry. Lawrence (I9I0) reports that in Washington it occurs commonly on the fruit of the blackberry and rarely on the fruit of the loganberry. The writer has not observed these fruits to be affected in New York State.

\section{ON THE CANES}

The presence of the disease is first noticed in the spring when the young shoots are about six inches high. Small reddish purple spots, which are slightly raised, are seen singly or in groups on the tender canes, first appearing a short distance from the growing tip. The spots enlarge slowly, and the centers become sunken and assume a pale buff color while the advancing margin is raised and purple. A single lesion is more or less oval in outline, the greater diameter lying along the shoot; but usually the spots anastomose and form irregular blotches which frequently encircle the cane (fig. I2, and fig. I3, A). In the center of each spot is a small pustule visible to the naked eye. Later in the season, with the further growth of the host, longitudinal cracks appear in the spots. During the winter these enlarge so that in the spring the second year's growth is often split to the pith (fig. I3, B).

A somewhat different type of lesion has been found on the shoots of the purple-cane and red varieties of the raspberry. It differs from the spot described above in that a knotty growth develops, which occasionally becomes twice the diameter of the normal cane. These knots arise from lesions formed when the tissue is very young and tender, and in some cases cause a distortion of the cane. This type of injury, which has never 


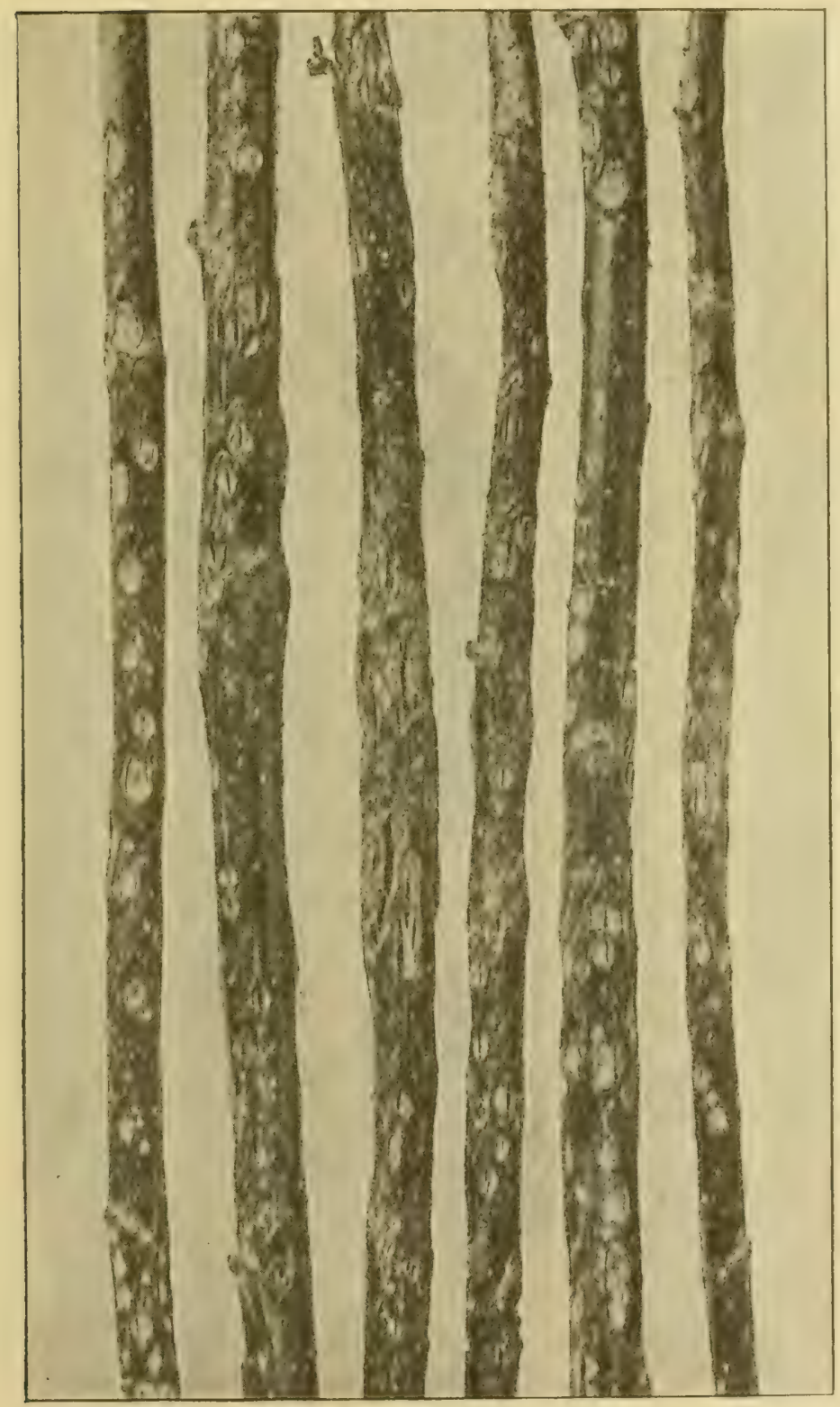

Fig. I2. ANTHRACNOSE LESIONS ON THE CANES OF RED RASPBERRY A severe infection, showing various stages in the development of the lesions 


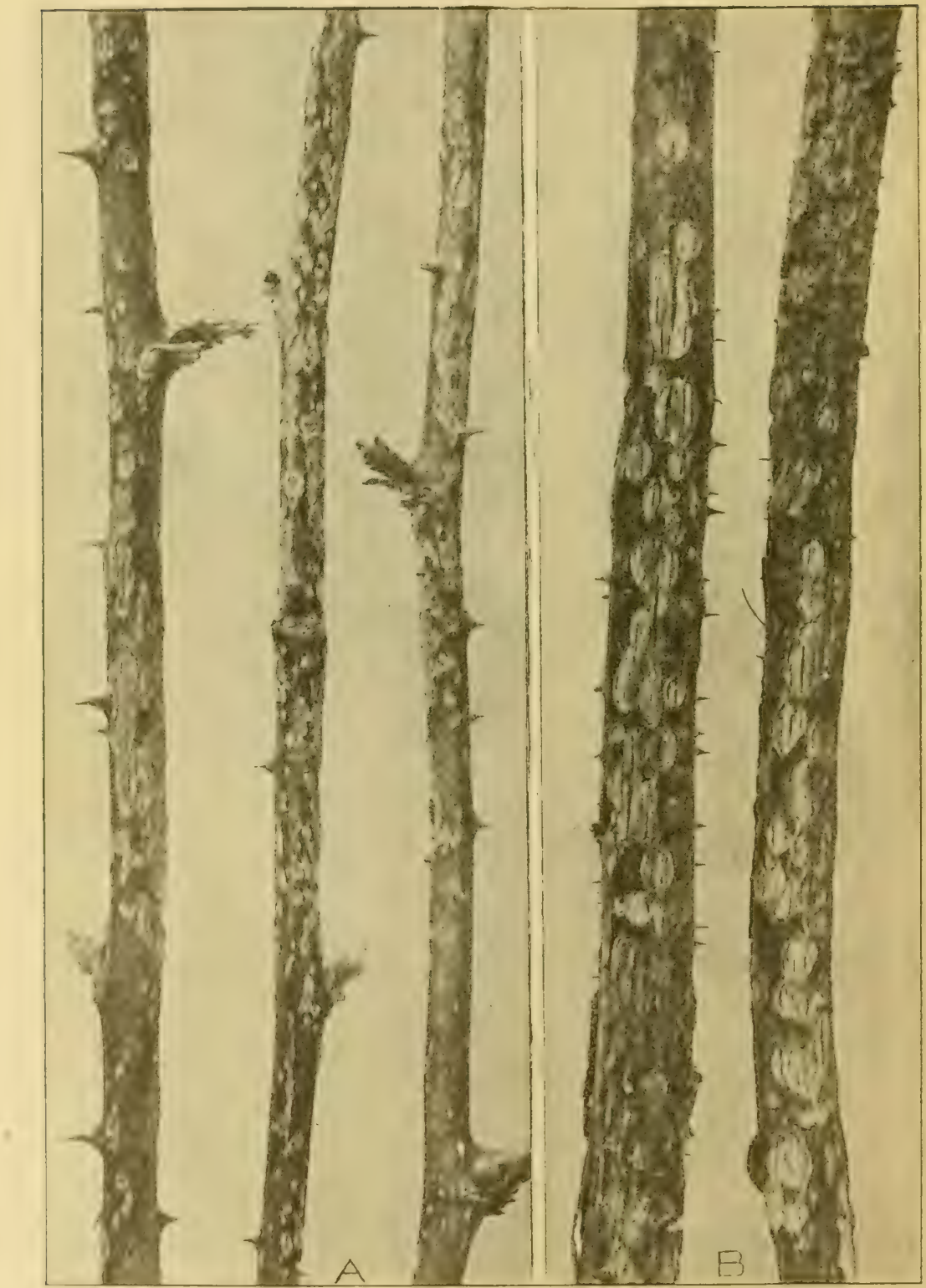

Fig. 13. ANTHRACNOSE ON SPECIES OF RUBUS

A, Lesions on the canes of blackberry; $\mathrm{B}$, lesions on the canes of black raspberry, showing the typical fissures 
been observed on the black raspberry, was first noticed by Stewart, Rolfs, and Hall (igoo).

As a rule the lateral branches are less severely affected than the principal canes. Occasionally young laterals are killed when they first develop. These branches become dry and the tissue is hard and brittle, while scablike lesions entirely girdle the base and extend up the young shoot. The lateral shoots that arise from two-years-old canes and bear the fruit, however, are never seriously diseased: Although spots often occur on them the lesions are small and cause comparatively little injury.

\section{ON PETIOLES AND PEDICELS}

Anthracnose is not found commonly on the petioles and the pedicels of the raspberry. When it does occur there the spots are similar to those on the canes, although frequently the purple margins are absent and the affected area is pale buff, raised and scablike. The diseased petioles and pedicels become brittle, while the fruit is retarded in its maturation in proportion to the severity of the infection.

\section{ON THE LEAVES}

The disease appears on the leaves of the raspberry somervhat later in the season than on the canes. Small purple spots with light-colored centers may appear scattered irregularly over the upper surface of the leaf, or they may be found in rows where the leaf is creased or folded (fig. I4).

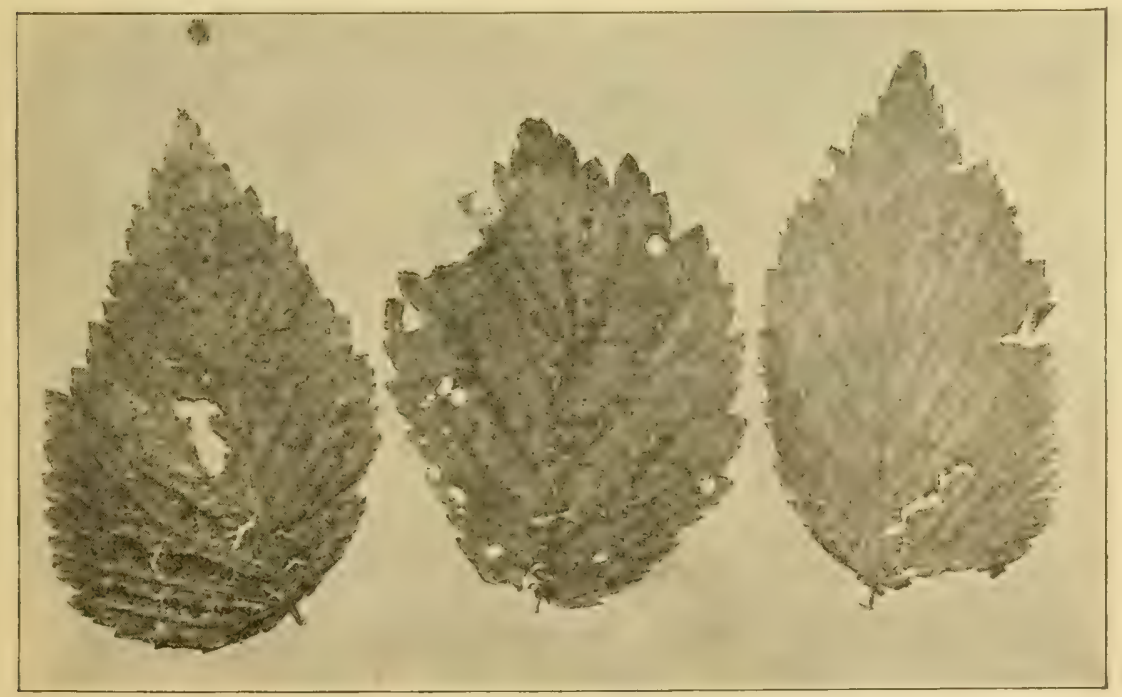

Fig. I4. ANTHRACNOSE DISEASE ON THE LEAVES OF RASPBERRY

The spots occur in rows, but not necessarily on the veins 
Frequently in the latter case the spots anastomose. Since the lecions are very small, about one to two millimeters in diameter, the foliage is not in jured to any extent by the anthracnose, although later in the seasnn the affecter leaves may become more or less ragrged. It has been observer also that in some cases the spots drop out and give the shothole effect characteristic of many leaf spots.

The common leaf spot of the raspberry, which may be confused with anthracnose, is caused by a species of Septoria. The lesion differs from that of the anthracnose disease in being irregular in outline and pale brown in color, with minute pycnidia just visible to the eye. In the case of the Septoria disease a yellowing and dying of the leaves nccurs.

\section{ETIOLOGY}

The inthracnose disease of the raspberry is caused by the fungous pathogene Plectodiscella veneta Burkholder.

\section{MORPHOLOGY}

The mycelium of Plectodiscella iencta when mature is hyaline and compused of minute cells many of which are globose. In all stages the fungus

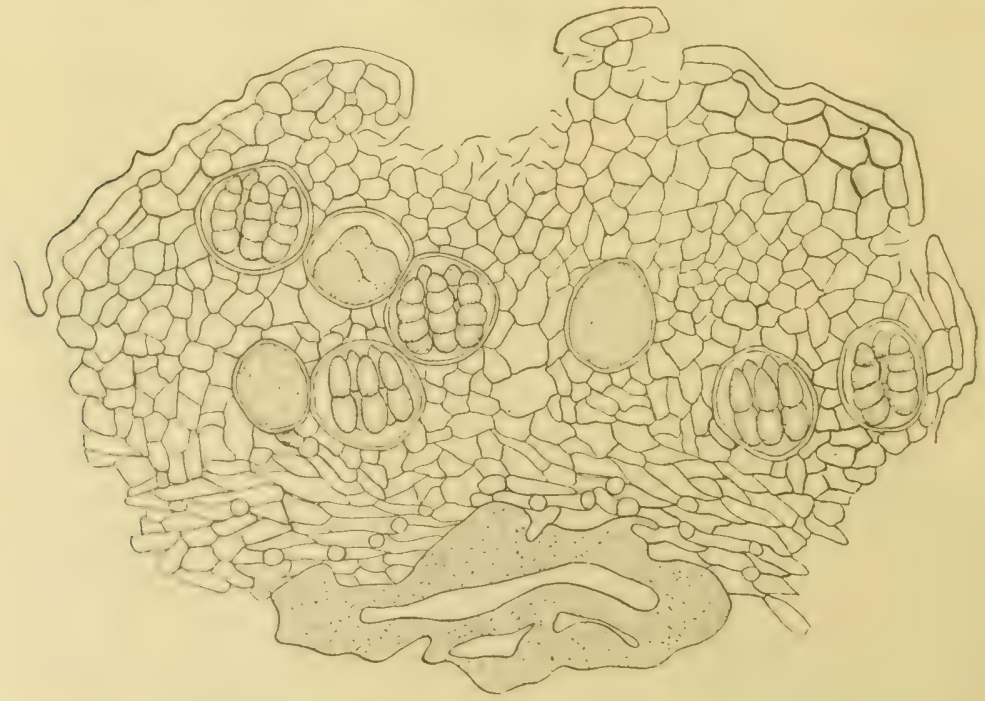

Fig. 15. ascocarp of plectodiscella veneta

Longitudinal section through the ascocarp, showing various stages in the development of the ascospores. Outlined with camera lucida from prepared slide. The tissue is somewhat shrunken. $\times 8.50$

i. very local and forms a stroma in the epidemal and subepidernal cells of the host. This stroma is frequently subcuticular. but never has it been 
observed to be entirely subepidermal. The tissue of which it is composed is in its mature condition hyaline, and raries from a pseudoparenchyma

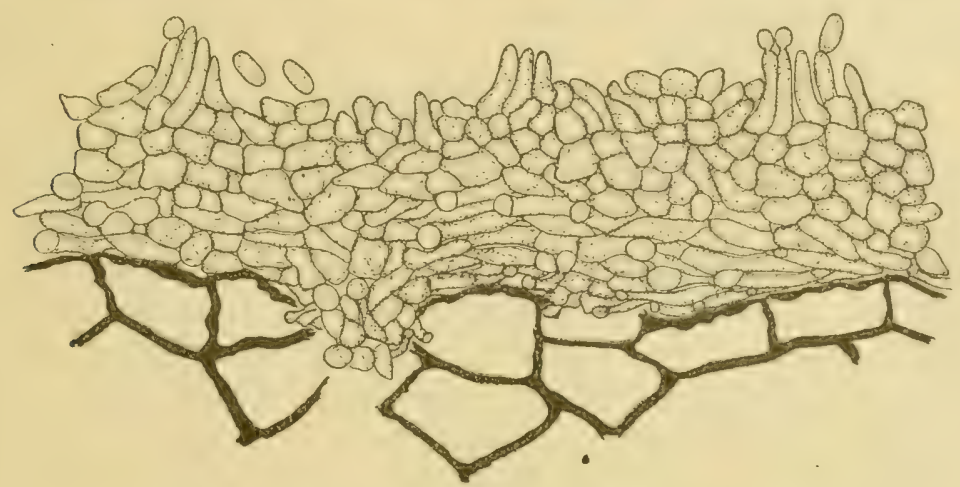

Fig. I6. ACERVUlus OF PLECTODISCELla VEnEtA

Section showing the differentiation in the upper and the lower layer of the stroma, also the conidiophores arising in groups. Outlined with camera lucida from prepared slide. The tissue is somewhat shrunken. $\times 850$

in the outer area to a plectenchyma next to the host cells. In the leaves the stromatic tissue consists only of one to several layers of fungous cells. The imperfect stage arises from this stroma both on the leaves and on the canes, while the ascigerous stage has been observed to arise only from the stroma on the canes.

The ascocarps of $P$. veneta are pulvinate, from deep brown to black, and about $75 \mu$ in diameter (fig. I 5). They are borne singly or in groups, and they frequently anastomose and give rise to variously shaped bodies. The dark color is due to a layer of thick-walled, brown cells which cover each fruiting body. These cells at maturity split apart and expose the tissue within, which is hyaline, pseudoparenchymatous, and usually in a state of disintegration. The cells of the ascocarps are somewhat larger and thinner-walled than those of the stroma. Globose, thick-ivalled asci, from 24 to $30 \mu$ in diameter, are scattered irregularly throughout the interior of the fruit body and either lie against one another or are separated by the fungous tissue. The ascospores are borne parallel to one another in the ascus. They measure from I8 to 2 I $\mu$ in length and from 6.5 to $8 \mu$ in width, and are hyaline, four-celled, ovate, and slightly curved, with constrictions at the septa. The basal cell is larger and more obtuse than the apical cell.

The imperfect stage of $P$. reneta has been known in literature as (jlocosporium renetum Speg. Short, unbranched conidiophores are produced, frequently in groups over the surface of the stroma, and these bear unicellular conidia which are held together in a mucilaginous substance (fig. I6). 
The conidia are hyaline. and from cublong to elliptical and in some cases slightly dumblell-shaped. They are characterized by having an oil globule at each end, and they measure from 5 to $7 \mu$ in length by from 2.5 to $3 \mu$ in width.

\section{NOMENCLATURE}

The conidial stage of the functs: was first collected by Spegazzini in ${ }_{18 ;} ;$ in Italy on Rubus chamacmonts, and was named by him (jlocosporium ienctum. In America the organism was first mentioned by Burrill (is S2) $_{2}$. He evidently either had not seen sperazzini's description or considered the two fungi to be distinct, since he gires no name to the pathogene. Burrill states, moreorer, that possibly the raspberry fungus belongs to the genus Cloeosporium, but he thinks the fact that the spores are not borne beneath the epidemis throws some doubt on its position. Ellis (Ellis and Ererhart. IS $S_{7}$ ) described the fungus under the name Glocosporium necator E. \& E.. although previously in a letter to Burrill he had referred it to the genus Ascochyta. The similarity of G. necator E. \& E. to G. venetum Speg. mas recognized by Ellis, but the two species were separated by him because the latter is foliicolous. From this it is evident that he had not observed the pathogene on the leaves of the raspberry. In the following year Scribner ( $188 \$$ ) pointed out the fact that since ( $i$. necator E. \& E. agrees in all characters with the fungus previously described by Spegazzini, and since it occurs on both the leaves and the canes, it should be known as Gloeosporinm venetum Speg.

In I9I4 the writer (I9I4) reported the discovery of an ascomycete which he regarded as the perfect stage of this fungus, and in a later paper (10); he showed the connection between the two forms. The fungus was siven the name Plectodiscella icneta. The only representative of the renus: Plectodiscella known previous to 1917 was $P$. Piri, described by Wimmichin (Iof 4 ) as occurring on the leares of apple and of pear. The mathlugy of the two species is strikingly similar and it is apparent that the asifernus statre of (ilocosporium ienctum belongs in the same grenus. Wible the excejtion of the work of Von Höhnel (1909), but little careful in c...igation has been conducted on this group of ascomycetes, and the s.tentatic forition of the grenus Plectodiscella is somewhat doubtful. Wimalin merely places it somewhere between the genus Elsinóe Rac. and He ine discomretes. When it is considered that the position of Elsinn is also inclefinite, the taxonnmic position of the genus Plectodiscella bermmes more difficult to determine. Both grenera, however, show close relatinnship, with the order Plectascales, and no doubt should be placed there. 


\section{LIFE HISTORY}

\section{The ascigerous stage}

During the season of I9I4 the fungus was kept under close observation in order to determine when the ascocarps begin their development. Repeated examinations of anthracnose lesions on young canes of the purple-cane raspberry, at Brant, New York, showed that the ascocarps berin to develop during the latter part of the summer. The sexual fruiting bodies were found more commonly on this hybrid. The perfect stage of the fungus has been collected by the writer also on the black raspberry and the red raspberry, while Rees (1915) has reported it on the blackberry

About the middle of August, when the immature ascocarps are first observed, they appear as minute spots, from deep brown to black, scattered singly or in groups over the buff-colored and sunken part of the anthracnose lesion. These spots are barely visible to the eye, and only visible at all because of the contrast in color with the surrounding tissue. At the end of the winter the entire lesion assumes a dark brown hue, and it is with great difficulty that the fruiting bodies are then observed, even with a hand lens.

In the early stages of its development the ascocarp is merely a raised part of the stroma, the tissue of which is but slightly differentiated, and the asci have not started to develop. A layer of brown cells covers the fruiting body, forming a more or less circular structure which gives the appearance of a shield, less perfect, however, than those found in the family Microtheriaceae. The cells near the center of the shield are thinnerwalled, and with the further growth of the tissue within they soon split apart in a stellate manner. By autumn the asci have appeared and are found as globose bodies filled with a homogeneous mass of protoplasm. In some instances the spores are formed by this time. The fungus may pass the winter in this condition.

In the autumn, or more often the following spring, the asci mature and the homogeneous mass of protoplasm gives place to eight four-celled ascospores. In the formation of these spores the middle septum is laid down much earlier than the other two, and so it is not uncommon to find two-celled spores. Later these two cells divide and the mature ascospore becomes four-celled. The constrictions formed at the septa during this second division are frequently not so great as at the first, or middle, septum. Occasionally one of the cells fails to divide and an ascospore of three cells is formed.

During the formation of the spores the disintegration of the fungous tissue about the asci takes place, and with the rupturing of the outer layer of the ascocarp the asci are exposed. Frequently the asci lying in this exposed 
comdition, surrounded by the remainder of the ascocarp, give the appearance of me of the true discomycetes. This, howerer, is brought about by the exrsistency of the outer cells of the shield-like layer which covers the immature ascocarp). In the presence of sufficient moisture the exposed asci elongate to approximately three times their usual length. This process is very rapid and may be observed under a microscope when a frament of tissue containing asci is placed in a drop of water. The lower part of the ascus remains fastened in the cavity in which it was borne, griving a conical shape to the body which raises itself above the surrounding tisste. The spores gather at the tip of the ascus and from there are ejected into the air. They have been canght at a distance of one centimeter above

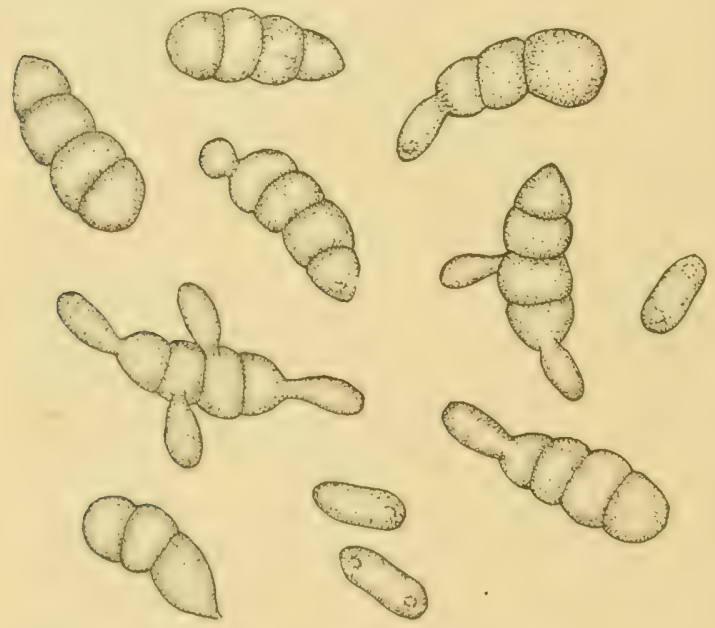

Fig. I7. Ascospores of plectodiscella veneta Showing various stages in the formation of the sprout conidia. $\times \quad 1132$ the lesions.

Even in a single ascocarp all the asci are never of the same age, and the ascocarps on the same cane seem to vary in this respect. In I9I5 mature ascospores were first observed about the first of June, while other ascospores were not mature until later in the summer.

The ascospores, like the conidia, have walls which are very gelatinous and sticky, and great difficulty was experienced in trying to pick up single spores by means of a glass tube, as dereribed by laarber." The spores adhere especially to the glass slides, annl it was innosicible (1) gret them into the bore of the tube. Single asci, however, could be separated in this manner.

When placed in tap, rain, or distilled water, or on nutrient agar, the mbature asospures germinate very readily. They swell somewhat, and within less than wo hours a short sterigma is produced from one or each w the cells. I spront conidium is formed, which is from oblong to ellipacial in shatge and is identical with the conidia of the fungus borne in the acervuli (fig. $1 ;$ ). When fully mature the sprout conidia drop from the - ierigmata but they do not germinate immediately. After a short period if rest, from twelve of twenty-four hours, a grem tube is dereloped and

\footnotetext{
6 Barber, Marshall A. On heredity in certain microorganisms. Kansas Univ. sci, bul, 4:3-48. 1907.
} 
mycelium is formed. When an ascus is placed in a drop of water or on agar, the spores within germinate by sending the sterigmata through the wall of the ascus and producing the sprout conidia on the outside. These in turn germinate. After the production of the secondary spores the ascospores shrivel and disintegrate.

During the spring and early summer the ascospores are ejected from the asci. Falling on the young shoots, apparently the spores produce the sprout conidia which later send forth germ tubes that penetrate the host tissue. Because of their gelatinous walls, the ascospores could readily adhere to the smooth surface of the cane and greminate when sufficient moisture is present. These steps, howerer, have never been followed by the writer.

\section{The imperfect stage}

As stated above, Plectodiscella icneta may pass the winter in the ascigerous stage. The ascocarps, however, are very rare and the pathogene as a rule winters over as mycelium in the canes. With the usual periods of rainfall in the spring, accompanied by warm. weather, a great many conidia are produced in the old lesions, and these conidia readily infect the young raspberry shoots which at this time are about eight to twelve inches high.

The germination of a conidium on a young raspberry cane has been observed only on canes in a moist chamber. Here the spore germinates by producing one or more germ tubes, which branch profusely and form a minute cushion of cells. The cushion adheres closely to the host and is not readily removed, evidently because of the hyphae which have begun to penetrate the cell or cells of the host beneath. It is difficult to determine whether the minute fungous mass is subcuticular or not. On the young shoots of the raspberry used (Rubus neglectus) the cuticle is poorly developed. Later, however, when the fungus has spread through the epidermal cells, the cuticle may be found to extend a short distance orer the lesion. After the pathogene has entered the cells of the host, further growth continues in the formation of a stroma, the center of which appears as a small pustule visible to the eye. This raised part of the stroma has nothing whatever to do with the fructification of the fungus, as one is at first led to believe, but is merely the accumulation of fungous cells at the point of infection. While the tissue of the cane is tender the mycelium grows rapidly, but growth is soon checked upon the hardening of the host cells at maturity. Consequently a lesion resulting from a single infection seldom reaches a width of more than one centimeter. With the further tangential growth of the cane underneath the lesion, the stroma is often torn apart, and during the second year it is found primarily about the edges of the spot. 
Shortly after the stroma begins to derclop, conidiophores arise, usually in sroups ower the surface, and these bear conidia. The conidia are embedded in a gelatinous substance which is soluble in water, and therefore they may be splashed by rain to the surrounding canes. According to Appel (i () 5 5), this gelatinous substance which covers the spores also aids them in sticking to the heary wax cuticle of the raspberry cane.

The conidia germinate within a period of from three to twelve hours in water and on various nutrient media, but the writer has never observed more than a forty-per-cent germination. From the few observations made their vitality appears to be short, although Scribner (I888) was able to germinate spores that had been kept in the herbarium for several months. Drying the conidia on a glass slide for twenty-four hours does not injure their vitality, but repeated drying causes their death.

It is possible that the fungus dies after the production of conidia in the spring, since the writer has found but few conidia in old lesions after early stmmer and these were evidently left from the early production. Furthermore, spores were never produced when diseased canes that had borne fruit were placed in moist chambers, and the writer has never been able to obtain cultures of the fungus from plantings of such tissue. The death of the pathogrene cannot be attributed to the dying of the host after fruiting time, as the fungus on one-year-old canes which have winterkilled may produce conidia in great abundance the following spring. Here it should be remembered that, although raspberry roots are perennial, the canes are biemnial. The fungus living on the latter has a similar life period, eren though it is not entirely parasitic on its host.

\section{PATHOLOGICAL HISTOLOGY}

Very little has been done by previous investigators on the pathological histulogy of raspberry affected with anthracnose. Scribner (I $88 S$ ) states that " the greatest injury is confined to the cambium layer, or the portion through which the sap) is conveyed in the process of growth." Paddock $(1, \mathrm{~s})$ ) slates that "it is not known that the fungus works into the wood lut its attackenccasionally cause the canes to crack and expose the pith.'

Is w the exat tissues invaded by the fungus and the various pathological conditions which arise in them, nothing has been written.

The follewing whervations were made on diseased canes of the Columlitun variety of raspberry. This is a purple-cane variety and possibly is more sererely attacked by the fungus than are any of the blackcap varieties. The lesions frequently develop to a greater extent on the former than on the latter, and thus a wider range of stages may be observed.

Infection takes place more readily on young and tender canes, and throushout the summer the small reddish purple spots indicating recent 
infection are found only on the tips of the shoots. During the early derelopment of the disease the epidermal and the outer cortical cells collapse. At this early stage the fungus has never been noticed in these cells, but since the hyphae are very slender and the dead host tissue becomes so deeply stained the mycelium would be difficult to detect. The parenchyma below this collapsed region is evidently affected with a toxin or enzyme either produced by the fungus or resulting from the death of the host tissue. The cells in this region divide very rapidly in a tangential plane. This hyperplasia of the parenchyma cells causes the young lesion to be slightly raised at first on the surface of the cane, but with further derelupment of the pathogene this tissue collapses and the lesion becomes sunken. A thin stroma then fills the cavity and a very small trace of the cortex remains or frequently its destruction is complete. During this time the organism continues its invasion of the parenchymatous cells between the vascular bundles. A hyperplasia of the phloem next occurs, but no further pathological condition arises within this tissue in case of late infection. On the other hand, with early and severe infection the phloem cells collapse and the fungus destroys the cambium and extends to the xylem.

Normally a ring of fibers is formed in the cortex, which are not in a continuous sheet but appear in groups associated with the phloem. If the pathogene reaches these before they mature, the fibers become abnormal or are completely suppressed. After their development, however, they are very resistant to the attacks of the fungus.

The xylem tissue is the least affected by the anthracnose disease, but if infection takes place when the vascular bundles are small the xylem ceases its normal development. It is difficult to determine whether this tissue is invaded by the pathogene, since only the outer edge shows the necrntic condition which might be indicative of the presence of the fungus. Frequently it is impossible to determine the position of the cambium, as the diseased phloem and xylem lose their distinctive characteristics and become fused. Although hypoplasia is exhibited in the xylem beneath the infection, it is offset by an excessive development of that tissue on either side of the diseased spot. This is likewise true of the phloem.

Because of the increased development of the vascular bundles on either side of the lesion, and the hypoplasia and destruction of the tissue within the lesion, an uneven growth of the cane results. Longitudinal fissures appear in the diseased area and later extend into the xylem and in some cases into the pith. This splitting of the cane is caused by the strain placed on the diseased tissue due to the continued tangential and radial growth of the surrounding normal tissues. It is delayed, however, to some extent by the development of a group of parenchyma cells which 
lake the place of the phloem and the inner cortex. In cross section this groul) of cells is wedge-shaped, with the apex extending toward the center of the canc, and in the outer edge small bundles of fibers frequently may be observed. This tissue collapses soon after development and is torn apart when the fissures occur in the lesion.

\section{CULTURAL CHARACTERS}

Miss Stoneman ( 1808 ) states that this fungus "does not adapt itself readily to artificial culture, and considerable difficulty was experienced before ol)taining a pure culture." In making plantings of diseased tissue the writer found that the fungus develops so slowly that contaminations

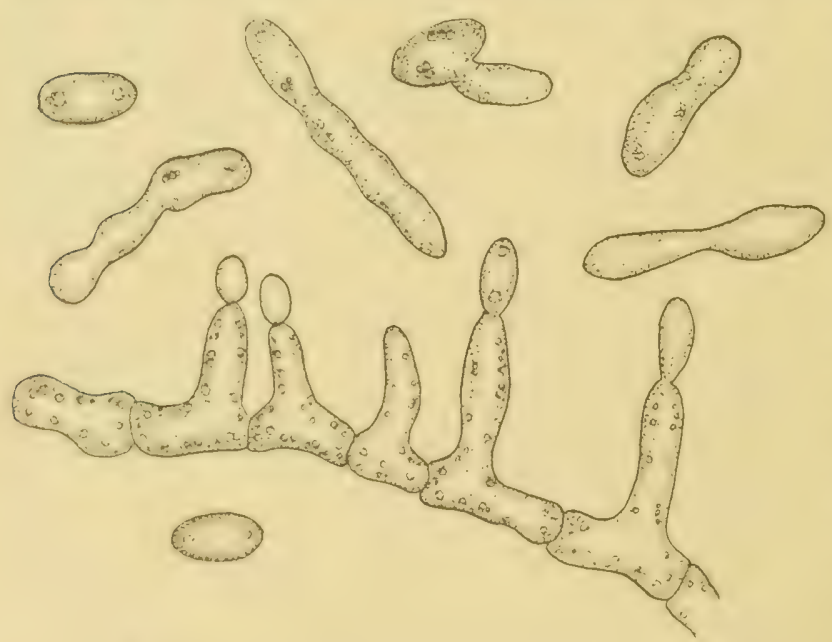

Fig. I8. CONidia of PLEctodiscella veneta

The conidia and conidiophores were produced in culture. Some of the conidia are germinating. $\times 1132$ are likely to grow over it. The growth of the organism from such plantings cannot be detected microscopically for five or six days, and a week more is required for sufficient development before the fungus can be removed to a test tube. Spore dilution plates are as satisfactory a method of isolating the pathogene

as any, and conidia are readily obtainable throughout the summer and exen litte in theatumm. A pure culture of the fungus may be obtained als fy inverting a sterilized petri dish containing a thin layer of nutrient asit wer at small piece of mispberry cane bearing ascocarps. When the phece of hark is moristened the ascospores are ejected from the asci and lindze on the atsir surface abowe. The spores can then be located easily wih a liw-magnifying microscope. By marking the position of the spores on the lewer side of the petri dish their germination and development can be whered. The ascospores first produce sprout conidia, but further devermment on the medium is identical with that from the conidia of the fungus. 
The growth of the fungus in culture is very peculiar. Miss Stoneman (r 898 ) states that several isolations were made before she was satisfied that she had obtained the desired organism. The conidia germinate on various kinds of agar within a period of from three to twelve hours (fig. i8). From a single conidium one or more germ tubes are developed, which at first grow rapidly. Septa are formed, the cells become swollen, and soon the conidium is indistinguishable from the cells of the mycelium. In tap or rain water, growth ceases at this stage. No appressoria have been noticed. On potato or nutrient agar, the primary germ tubes branch, and their cells, which are globose, form a more or less compact mass. The colony is circular in outline and as the mycelium grows older the color changes to a pale vinaceous pink. Hyphae radiate in all directions from the fungous mass but ionly for an exceedingly short distance. On media containing a small amount of agar a more nutritive growth occurs, the hyphae of which are filamentous, with occasional globose cells.

The aerial growth of this fungus in culture is comparatively slow, and continues as a pilingup of cells forming a wrinkled mass having the appearance of sclerotia (fig. I9). In some cases this mass has a shining appearance, while in others fine aerial hyphae are formed over the

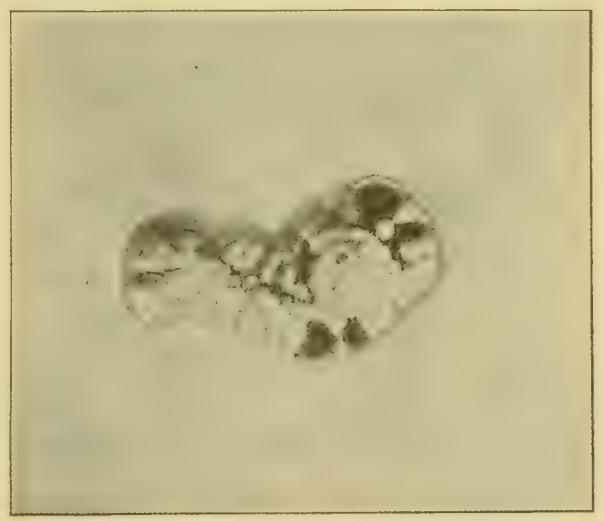

Fig. 19. CUlture of Plectodiscella VenETA ON POTATO AGAR CONTAINING I PER CENT OF GLUCOSE

compact growth. The color of the culture varies from light russetvinaceous to maroon, while the edges of the colonies are lighter in color due to the younger mycelium. The cells of the hyphae in the young colonies are very minute but become somewhat larger as they grow older. The diameter of the filamentous hyphae is from I.5 to $4.5 \mu$, while frequently a globose cell measures as much as i $4 \mu$ (fig. 20 ).

When the organism is cultured on potato agar containing glucose, the growth is much more rapid and aerial mycelium is formed which gives a pale brown or white downy appearance to the sclerotial growth. With the addition of glucose there is also a reduction, or at least a retardation, in the intensity of color production. On potato agar containing five per cent of glucose, the culture is pale brown with the characteristic red color developing next to the medium. On cornmeal agar the fungus has a brilliant red appearance, while on sterilized bean pods the growth is 
sclerotial and from cinnamon buff to maroon in color. On cellulose agar the fungus grows very slowly, there being only a slight digestion of the cellulose in the immediate proximity of the fungous mass.

Conidia are seldom produced in culture, and some difficulty was experienced in obtaining spores for use in inoculation experiments. It was founcl that a sudden change in the humidity of the culture brought about:

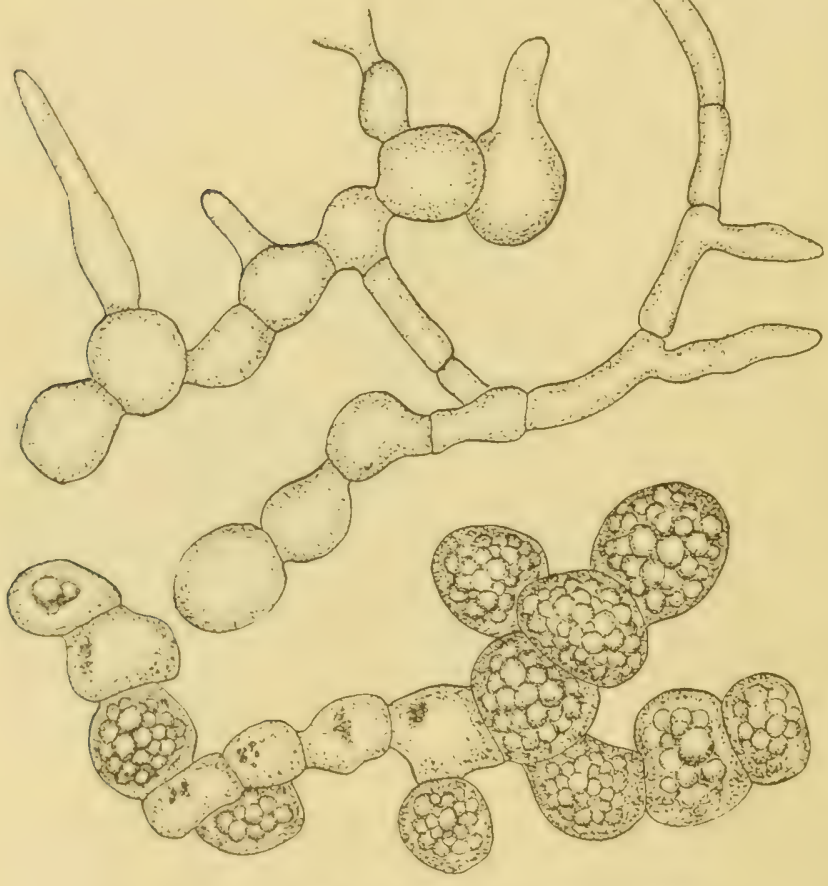

Fig. 20. Mycelium of pi.ectodiscella veneta

a production of conidia in sufficient numbers for use. It is to be noted, however, that the production of conidia is not continuous. The fungus was removed from a dry atmosphere to very moist conditions. This sudden change caused a production of conidia almost immediately, very similar to the manner in which they are produced in nature. Small conidiophores arise over the

The older cells are globose and usually filled with oil globules and red fungous mass and pigment. The mycelium is from a culture on potato agar. $\times$ I132

bear conidia which are similar to these occurring on the canes. When Plectodiscella winta is wown comtinutusly under moist conditions, few or no spores are prorluced.

\section{INOCULATION EXPERIMENTS}

\section{Inoculations with spores from the Gloeosporinm stage}

The grofof of the pathogenicity of the fungus repended on its constant as cuclation with the anthracnose until 1010, when Lawrence made a few innulation experiments. Ife used the fruits of the blackberry, and inoculaier them with conidia trom the leaves and the canes. He was unable 
to obtain spores of Plectodiscella veneta in culture. Typical lesions were formed on the drupelets after an incubation period of from fifteen to forty-eight hours.

During the summer of I9I 3 the writer conducted a series of inoculation experiments on young raspberry canes of the Columbian variety, which were emerging from the ground. Cotton-pluggred lamp chimneys were placed over these shoots, and when they were about six to eight inches high they were sprayed with a suspension of $P$. veneta conidia in water. The conidia were taken from the lesions on older canes, and in a few cases from pure cultures on potato agar, but in no case did more than thirty or forty per cent of them germinate. All inoculations were made in the erening, to avoid the evaporation of the drops of water containing the spores, and the lamp) chimneys were allowed to remain over the young plants for two or three days. Check plants were used. Many of these experiments were destroyed, as they were conducted in a field which was being continuously cultivated. The final data obtained, therefore, were relatively few and scattered.

Inoculations were made on the following dates: May 26, June 20 and 23. July I6, I8, and 29, and September I. Fifty-six of these experiments were completed but infection occurred only in eighteen cases. The incubation period was three days for seven experiments, four days for four, five days for five, and seven days for two. The shortest period was during the warmest weather, while during cool weather no infections occurred. Aside from climatic conditions, the causes of the low percentage of infection were possibly poor germination of the conidia, the drying of the drops of water, and the condition of the host plant. When the host tissue becomes hard, infection does not take place. Other factors, not sufficiently understood, no doubt entered into the experiments.

\section{Inoculations with spores from the ascigerous stage}

In order to make certain the connection between the ascigerous form and Gloeosporium venetum Speg., a series of inoculation experiments were conducted. The use of ascospores as an inoculum was impossible, since very few could be collected owing to the scarcity of the ascocarps and their irregularity in time of maturing. Also, it is difficult to make certain that the ascospores are separated from the conidia unless the former are collected by causing them to be ejected on plates of agar. The most satisfactory method appeared to be the use of conidia for inoculation from a culture of the fungus that had been developed from a single ascospore.

Such a culture was obtained, and was grown on three-per-cent potato agar until large, sclerotia-like masses were formed. These fungous 
masses were then transferred to sterilized bean pods in tubes containing several contimeters of water. The bean pods served primarily as supports on which the fungus comld be placed above the water. The cultures were then placed in anduator at a temperature of $24^{\circ} \mathrm{C}$., and by the end of three days a sulficient number of conidia were produced. By dropping the funguris mass into a small quantity of water the spores readily fell ofi and conlat be sprayed on the infection court. The germination of these coniclia was fairly rapicl. a serm tube being dereloped in about five hours:

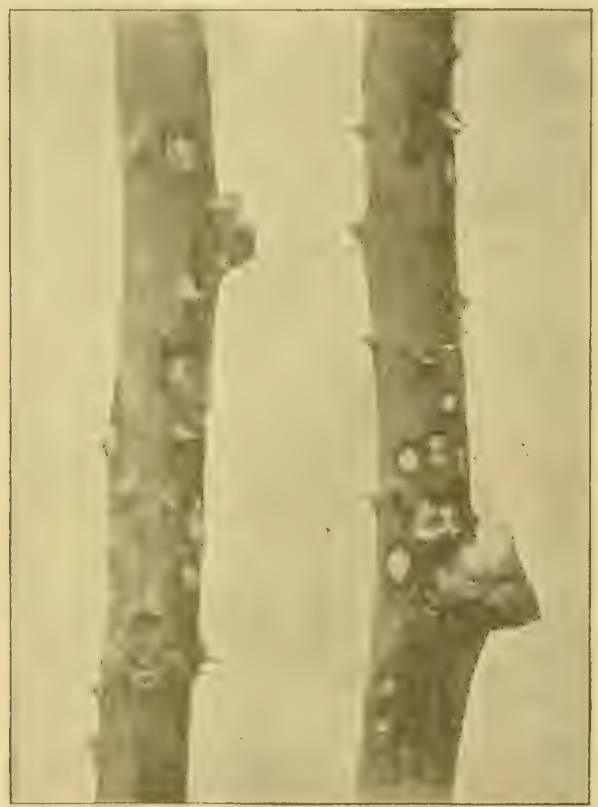

Fir;, 21, ANTHRACXOSE T,ESTONS ON CANTS OF

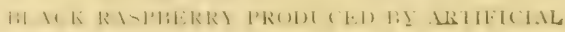
IXOCUT. $T$ TION

The canes were inoculated on April I5, 10I5, with

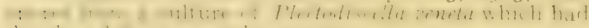

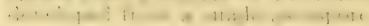
but the proportion of germination was low, in most cases between five and ten per cent.

Early in the winter of $1914^{-15}$ a number of roots of the Columbian variety of raspberry were planted in the greenhouse. Owing to the earliness of the dormant period and to the unfavorable conditions within the greenhouse, the plants grew slowly and gave a very stunted growth. All inoculation experiments with these plants gave negative results. As already stated, the anthracnose lesions appear only on tender succulent canes, and apparently the canes which had developed slowly on the green-house plants were too hard and woody for the fungus to infect.

Later, abrut the first of March. I9I5, a ferv raspberry plants of a recl variety, which were tencler and growing rapidly, were procured. () March + two cances were sprayed with a stuspension of coniclia

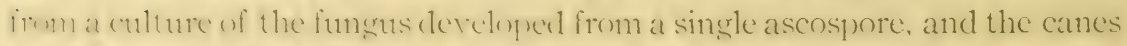
wore covered with bell glasses linew with moist filter paper. These glasses

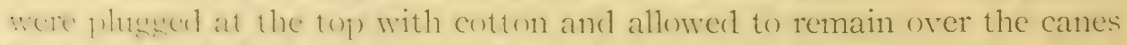
fir two days before remoring. Two other canes in the same bed remained untreated. On March 20, small purple spots had appeared on one of the canes. These infections grew slowly, much more slowly than an anthracmes lesion developing in the field, but spots typical of those caused hy lithesprimm ienctum were produced. Microscopical examination of the spots showed conidia of Gloeosporium renetum. 
Again on April 15 four tender canes of a blackcap variety of raspberry were sprayed with a suspension of conidia as above. Bell glasses were placed over them as in the previous experiments, and one check plant was used. A sample of the conidia used was placed in a drop of water on a slide, and about eight per cent of the spores germinated. After about a week, on April 2 I, a number of small purple spots had appeared on the four canes and these later developed into typical anthracnose lesions (fig. 2I). The check plant remained normal.

\section{Cross-inoculations}

Although no cross-inoculation experiments were conducted to test the ability of the pathogene isolated from one species of Rubus to infect another species, some data regarding this are at hand. In the experiments described above, the culture of the fungus from a single ascospore was isolated from the hybrid known as Rubus neglectus. The pathogene then produced infection on both Rubus occidentalis and Rubus idaeus var. aculeatissimins. The cultural characters of the fungus isolated from these three species, as well as from the blackberry (Rubus sp.), are identical.

\section{THE EFFECT OF WEATHER CONDITIONS}

Practically nothing is known as to the exact effect the diseased canes have on the yield of fruit. No experiments have been conducted to determine the relationship and it is very difficult to estimate. Observations show, however, that the decrease in yield due to the disease varies considerably with weather conditions. This variation may be attributed largely to the fact that both the pathogene and the canes are biennial. The infection period of the fungus is during the early summer when the canes are in their first year's growth, while fruit is not produced until the second year. Therefore the weather conditions that prevail both throughout the infection period and at fruiting time influence the rield. If during the first year's growth of the canes there is an abundance of rain and damp cloudy weather, the young shoots in a field where the anthracnose exists become severely diseased. Such weather is effective only the first part of the season, as practically no infection occurs after July. Furthermore, if dry weather prevails the following year when the canes produce fruit, the berries mature under very unfavorable conditions. They are subject not only to the dry weather, but also to the diseased condition of the canes where the conductive tissue is impaired. It is during such combinations of seasons that the loss to the raspberry crop) is so noticeable, while in a season when there is plenty of moisture the diseased canes may produce a good yield of berries. 
Canes that are affected with anthracnose are, as a rule, more susceptible to winter injury than are unaffected canes. In a field in which the disease is present, the canes that are found to have been killed during the winter are the ones that were severely affected by anthracnose and other diseases.

\section{CONTROL}

\section{CULTURAL METHODS}

It has been observed by the writer that cultural methods greatly favor the distribution of the pathogene to the new raspberry plantings. The method of propagation of the blackcap and the purple-cane raspberry is no doubt accountable for this. These varieties are propagated by means of tip) layers, which many growers do not remove in the spring until the young shoots have reached a height of a foot or more. By this practice it is maintained that the young plants are afforded a better chance of development. However, during this period the old diseased canes act as a source of inoctlum to the new shoots, which become infected and thus the disease is carried to the new plantation. On the other hand, if care is taken to dig the roots before they sprout or before the fungus on the old anes sporulates, which in New York State is sometime near the middle ui May, a healthy setting can be obtained. In the case of the red varieties, which it is necessary to propagate by means of suckers, the young plants should be procured from fields where it is known that anthracnose does not exist, or the canes should be carefully examined for lesions of the discase. The red varieties of the raspberry are very resistant, and thereiore it is not uncommon to find a field free from the disease, from which young suckers may be selected. As a raspberry plantation is comparatively short-lived, the selection of healthy plants at the beginning is a long step in the control of the disease. Moreover, observations inclicate that the pathogrene does not spread rapidly from one field to inuther. The character of the fungus would further substantiate this vicrs, as the sticky walls of the conidia render them not readily adlapted to dissemination by the wind.

The cradication of anthracnose after it has once become established in a ficlel is a difficult process. Pruning out the diseased canes has been recommentecl, but this is not desirable in the majority of cases since wisully the disease has become widely spread before it is noticed and witheut the entire cradication of the sources of inoctulum but little good can be accomplished. Sturgis (1900) cites an instance in which the majurity of infected cances were removed and the disease was checked. The season was dry. however, and this probably accounts for the reduction in infection. No doubt the remoral of 0 ' 1 canes immediately 
after the fruiting season is good cultural practice, but from the standpoint of checking the disease it is beneficial only in obtaining better aeration. Thorough cultivation, especialiy the eradication of weeds, likewise is advantageous, or any measure that has a tendency to keep the canes free from persistent moisture.

\section{SPRAYING}

Numerous attempts have been made to control anthracnose by spraying, but the results in most cases have been questionable. Since he found the raspberry disease so similar to anthracnose of the grape, Scribner (ISSS) recommended spraying with iron sulfate when the plants were in a dormant condition, and using bordeaux mixture if subsequent applications were necessary.

Paddock (1897). conducted spraying experiments in a black rasplberry plantation for three years with doubtful results. At least he came to the conclusion that spraying was not a profitable operation, but the data given by him may be interpreted otherwise. His experiments briefly are as follows:

The first three rows in the raspberry plantation were sprayed when domant with copper sulfate, using three pounds to eleven gallons of water: the next three rows were treated with a saturated solution of iron sulfate in water; the last three rows were left unsprayed. This plan was repeater five times. The two treated series were then followed with five applications of bordeaux mixture. The yields of berries are given on the three series for three years. The spraying was begun in 1894 , and therefore the yield in 1895 was the first on treated canes. The yield in that year was much increased over that of the preceding year. For the treated rows there was an increase of I 7 I per cent and I 48 per cent, respectively, while for the check row the increase was only 39 per cent. In I 896 there was not such a great difference in the yields, but the infection, even on the check rows, was very slight. Paddock compared his data one year at a time and did not take into consideration the fact that the spraying of the canes one season affected the yield the following year. Therefore, with the present interpretation of the results obtained by Paddock, there seems to be a pronounced indication that spraying would be profitable. at least in years when the anthracnose infection is severe.

Rees (I915) claims that blackberry anthracnose in the northwestern United States can be controlled by spraying. This, however, is hardly comparable with spraying for the control of the same disease on the raspberry. The benefit derived from treating the blackberry plant is in preventing berry infection, while on the raspberry the fruit is never infected. 
During the summer of I9I I Dr. P. J. Anderson conducted spraying experiments in raspberry fields at Brant, New York. This work was continued by J. H. Muncie during the summer of I9 12 , and by the writer during the seasons of $19 \mathrm{I} 3$ and I9I4, after which the experiments were brought to a close. A large number of spray materials, alone and in combination, were used. The results of the experiments were recorded for the most part on the basis of percentages of infected canes. This in itself is unsatisfactory, as it does not show the severity of infection and gives no indication as to the effect of the spray on the yield of fruit, which is really the ultimate aim. Thus rery little data were obtained indicating that spraying was effective.

A few well-checked experiments, however, are worthy of recording. In two plats, each containing approximately one hundred and thirty-two bushes, three applications of bordeaux mixture, $+-4-50$, reduced the number of diseased canes to 23 per cent and I 6 per cent, respectively. while the untreated bushes showed infection to the extent of 77 per cent and $7 \mathrm{I}$ per cent, respectively. The first application was made when the young shoots were from eight to ten inches high, and the following applications were made at intervals of two weeks. These experiments were repeated for several seasons, with similar results. After the third application the ripening of the fruit prevented further treatments, although the lateral branches were not fully mature and occasionally during this period infections occurred. These infections were observed only in a few cases, however, and then they were not severe. Spraying after fruiting linne is useless for sereral reasons. Infections seldom take place late in the season, and furthermore the new growth that develops after August is removed when the plants are pruned the following spring.

Besides bordeaux mixture various other chenicals were used. Limesulfur, self-boilerd lime-sulfur, and iron sulfate were tested, but none of these sare satisfactory results. The athesive quality of the iron sulfate in combination with the other spray materials also was investigated, but sufficient benefits were not observed to warrant recommending its use. Lime-sulfur, I gallon to to gallons of water, precipitated with iron sulfate, $7 \frac{1}{2}$ frumds to 100 gallons, gave a reduction in the percentage of infected cances. The spraying, howerer, dwarfed the plants considerably, causing them to bear small fruit with an insipid flawor. Bordeaux, on the other hand, caused only a slight burning of the tender leaves.

The application of a spray solution when the plants are in a domant mirlitim, as sugrested by several investigators, was tested thoroughly during four seasms. Various strengths of iron sulfate, the greatest leing z pruncls of the material to I gallon of water, copper sulfate + pounds (1) 5o walloms of water, and lime-sulfur i to 8 , proved to be of no benefit. 
The chemicals evidently do not penetrate far enough into the lesions to kill the pathogene, or else they fail to remain on the plants for a sufficient length of time to prevent the fungus from sporulating. Although the iron sulfate did not injure the buds, it caused the canes to turn black. giving the plants the appearance of having been burned over by fire; but this caused no harmful effects to the plants. This blackening of the canes was observed on the Columbian variety, and whether or not it occurs on all varieties of the raspberry is not known.

The yield of berries was recorded in only one experiment. On two rows, with approximately sixty-six bushes each and with 44 per cent of the canes diseased, there were estimated to be about 360 quarts more per acre than on two check rows with 90 per cent of the canes diseased. The treated plat had been sprayed with bordeaux and was separated from the untreated plat by two rows. This is but an indication that spraying is beneficial, and no adequate conclusions can be drawn from so small an experiment. More data relating to the effect of diseased canes on the yield of the fruit are needed, and until they are obtained no conclusive proofs can be furnished that spraying to combat the anthracnose of the raspberry is a profitable practice. 


\section{BIBLIOGRAPHY}

Appel, Otto. Discase resistance in plants. Science 11. S. 4I:773-7\$2. I9I 5 .

Bi'nholz, A. B. A survey of small fruits in western New York. Thesis for degree of M. S. in Agr., Cornell University. (Unpublished.) IOII.

Burkholder, W. H. The perfect stage of the fungus of raspberry anthracnose. (Abstract.) Phytopath. 4:407. I9I4.

- The perfect stage of Gloesporium venetum. Phytopath. 7:83-91. 1917.

Burrill, T. J. Blackberry and raspberry cane rust. In Notes on parasitic fungi. Agr. rev. $\mathbf{2}^{4}: 89-92$. 1882.

Cooke, M. C. Raspberry anthracnose. In Fungoid pests of cultivaterl plants, p. I47. 1906 .

Craig. John. Anthracnose of the raspberry (Gleosporium venetum). Canada Exp. Farms. Rept. I895:123-I24. I896.

Detmers, Freid. Diseases of the raspberry and blackberry. In Ohio Agr. Exp. Sta., Bul. 6: I24-I3I. I89I.

Ellis, J. B., And Everhart, B. M. Gloeosporium necator, E. \& E. In New species of fungi from various localities. Journ. myc. 3: I 29 . I 887 .

Grenen, Sancel. B. Cane rust of raspberries (anthraciose). In Univ. Minnesota Agr. Exp. Sta., Bul. 39:230-23I. I894.

Halsted, Byron D. The anthracnose of the rose. New Jersey Agr. Exp. Sta. Rept. I4 (I893):40I-405. I894.

Hönned, Franz vox. Revision der Myriangiaceen und der Gattume Saccardia. In Fragmente zur Mykologie. K. Akad. IViss. [Vienna]. Math.-Naturw. K1. Sitzber. I 18:349-376. I909.

J.1:Kson, II. S. Anthracnose of raspberry, blackberry, loganberry, etc: In Diseases of small fruits. Oregon Agr. Coll. Exp. Sta. Biennial crop pest and hort. rept. I9II-I9I2:26I-263. I9I3.

LAWRENCE, W. H. Anthracnose of the blackberry and raspberry. Washington State Coll. Agr. Exp. Sta. Bul. 97: I-I8. I9 Io.

Mi.lipine, D. Two fungus diseases of the raspberry - root-rot ancl anthracnose. Victoria Dept. Agr. Guides to growers, no. 32:1-I2. 1897.

Mhssize, Gronge. Gloeosporium venetum, Speg. In A text-book of plant diseases, p. 428 . I907.

Orton, W. A., And Ames, Adeline. Plant diseases in 1907. U. S. Dept. Agr. Yearbook 1907:577-589. (Reference on p. 580-581.) Igo8.

Padpock. Wisteli. Anthracnose of the black raspberry. New York (Geneva) Agr. Exp. Sta. Bul. I24:26I-274. I897.

Pavtox, J. IIoyes. Raspberry anthracnose. Ontario Agr. Coll. and Exp. Farm. Rept. 20 (1894):7. I895. 
Raciborski, M. Elsinoe Rac. nov. gen. Magnusiellae affinis. In Parasitische Algen und Pilze Java's, Part I, p. I4-I5. 1900.

REES, H. L. Experimental spraying for blackberry anthracnose in I9I5. Western Washington Exp. Sta. Monthly bul. $3^{8}:$ I-IO. I9I5.

Scribner, F. Lamson. Anthracnose of the raspberry and blackberry. U. S. Dept. Agr. Rept. Comm. Agr. I887:357-36r. 1888.

Sorauer, Paul. Handbuch der Pflanzenkrankheiten 2: I-550. (Reference on P. 4I8.) I908.

Spegazzini, C. Gloeosporium Venetum. Michelia I:477. I879.

Stewart, F. C., Rolfs, F. M., and Hall, F. H. Raspberry diseases. Anthracnose. In A fruit-disease survey of western New York in I900. New York (Geneva) Agr. Exp. Sta. Bul. I9r:328-329. I900.

Stoneman, Bertha. A comparative study of the development of some anthracnoses. Bot. gaz. 26:69-120. I898.

STURGIS, W. C. On the prevention of raspberry-anthracnose by cultural methods. Connecticut (New Haven) Agr. Exp. Sta. Rept. 23 (I899): $274^{-276 .}$ I900.

TAFT, L. R. Raspberry anthracnose. Amer. gardening I5:22I. I894.

Thaxter, Roland. Gloosporium necator E. \& E. Connecticut (New Haven) Agr. Exp. Sta. Rept. I889: I72. I890.

Woronichin, N. N. Plectodiscella Piri, der Vertreter einer neuen Ascomyceten-Gruppe. Mycol. Centbl. 4:225-233. I9I4. 


LIBRARY OF CONGRESS

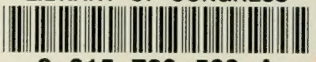

$\begin{array}{lllll}0 & 015 & 793 & 580 & A\end{array}$ 